\title{
Characteristics of Amino Acid, Micronutrient and Probiotic Isolated from Dadih and Their Benefits for Pregnant Mothers and Outcomes in West Sumatra, Indonesia
}

\author{
Helmizar $^{1} \&$ I. S. Surono ${ }^{2}$ \\ ${ }^{1}$ Department of Nutrition, Faculty of Public Health, Universitas Andalas Padang, Indonesia \\ ${ }^{2}$ Department of Food Technology, Faculty of Engineering, Bina Nusantara University, Jakarta, Indonesia \\ Correspondence: Helmizar, Department of Nutrition, Faculty of Public Health, Universitas Andalas Kampus \\ Unand Limau Manis, Padang - 25163, Indonesia. Tel: 62-7513-8613. E-mail: eelbiomed@gmail.com; \\ helmizar@ph.unand.ac.id
}

Received: October 9, 2019 Accepted: December 14, 2019 Online Published: December 29, 2019

doi:10.5539/gjhs.v12n1p116

URL: https://doi.org/10.5539/gjhs.v12n1p116

\begin{abstract}
Dadih is a traditional fermented buffalo milk consumed by the Minangkabau people in West Sumatera Province, Indonesia, especially in Bukittinggi, Padang Panjang, Solok, Lima Puluh Kota, and Tanah Datar districts. The objective of this study was to identify amino acid and strain of acid lactic bacteria isolated from dadih and to evaluate the benefit of dadih intervention during pregnancy on the nutritional status of an infant's birth. This study was initiated with DNA extraction from bacterial cultures, Ribosomal DNA amplification, and sequencing, analysis of amino acid using UPLC. The intervention was conducted in two districts on 138 pregnant mothers for 6 months. A prospective cohort study was conducted on a follow up of a previous randomized controlled trial. This study was conducted in two districts in West Sumatera Province from April 2018 to July 2019. Spontaneous probiotic species of dadih strain were identified in this study: Lactobacillus Plantarum, Lactobacillus casei, Lactobacillus durans, Leuconostoc pseudo mesentoroides, and Lactobacillus cactis. Glutamic acid was the highest quantity of non-essential amino acid in dadih $(16.28 \mathrm{mg} / \mathrm{g})$, while Lysine and Leucine were the highest essential amino acids $(7.22$ and $6.42 \mathrm{mg} / \mathrm{g})$. The study revealed that after a 6-month intervention, about $66.7 \%$ of infants birth weight $>3000$ grams and only $2.1 \%$ of infants having birth weight $<2500$ grams for Dadih Group and about $60.0 \%$ had infant birth weight $>3000$ grams and $4.4 \%$ infants with low birth in Control Group. The result of this study shows that there are more benefits in pregnant mothers' weight gain and infants' birth weight until a six-month follow up from pregnant mothers in Dadih Group than Control Group. The results of the follow-up study show that infants from mothers supplemented with Dadih Zinc Group have significantly less undernutrition status as compared to the Control Group $(p<0,05)$. The results also show that dadih has a sufficient amount of protein to fulfill the nutritional need for pregnant mothers and the outcomes.
\end{abstract}

Keywords: Amino acid, probiotic, dadih, pregnant mothers, outcomes, Indonesia

\section{Introduction}

Dadih is a traditional food that is popular in several West Sumatra districts, such as Bukittinggi, Padang Panjang, Solok, Lima Puluh Kota, and Tanah Datar district. Dadih is a source of probiotics that can increase human health (Surono 2015a, 2016). It can be referred to as a Minangnese yogurt. Although has been part of the Minangkabau people's diet for along time, its consumption has decreased in recent years because most people, especially the youth, are unaware of its nutritional values. Therefore, it is important to reintroduce dadih to the community by using different methods, such as a bamboo cup as its packaging.

For this purpose, many kinds of bamboo can be used, such as Talang bamboo and Buluah Lapoh. Talang bamboo diameter is about $5-8 \mathrm{~cm}$ while buluah Lapoh has a smaller diameter $\pm 3-4 \mathrm{~cm}$. First, the bamboo should be cleaned and dried before used. Bamboo can be cleaned eitherwith a duster or with a coconut husk. Bamboo is dried under the sunlight for 10-15 minutes. Dadih makers still use traditional ways to produce dadih. Sometimes they do not pay much attention to sanitation and hygiene while using a non-pasteurized process and unclean bamboo cups. Because this rather unsafe process has been passed down from generation to generation, 
it is hard to persuade dadih makers to adopt new methods.

As technology and science advance, government and certain parties such as researchers have contributed to the development of dadih makers in West Sumatra. Sequence training on making dadih is provided to the local community to enable them to produce high-quality dadih. Its quality improvement is expected to attract consumer interest.

One of dadih's benefits is lactic acid produced from its fermentation at room temperature for 24-48 hours. Soruno (2016) reported that Lactobacillus Plantarum strain IS-10506 is dominant in dadih. Lactococccus is the dominant microbiota composition founded in all samples of dadih from West Sumatra (Venema, K and Surono, IS, 2018). Lactic acid is considered as a probiotic that plays an important role in regulating the digestive system of humans and animals. Some other studies suggest that the result of bacterial isolation in dadih has 36 dominant lactic acid strains. Metabolism of lactic acid can inhibit pathogenic bacteria, improve the immune system, prevent constipation, lower cholesterol, antimutagenic, anticarcinogenic, antivaginitis, and produce vitamin B and bacteriocin (Pato, 2003). The possible mechanism of actions includes inhibition of pathogenic bacteria. There was no adverse effect of probiotics on pregnancy outcomes including gestational age, birth weight, malformation and complication of pregnancy (Wibowo et al., 2015). The objective of this research is to identify the characteristics of amino acid, micronutrient and probiotic dadih in Agam and Tanah Datar Districts and follow up on the sustainability benefit of the effect of dadih and zinc supplementation during pregnancy on the outcomes. This research is of importance because not only does it seek to increase dadih quality but it can also be used as a theoretical basis for further intervention research.

\section{Research Material and Method}

Dadih from Agam and Tanah Datar districts, West Sumatra Province, was used in this study. A community intervention trial was conducted from January to December 2018 and follow up in 2019. Laboratory measurement was conducted in several locations such as the Biotechnology and Microbiology Laboratory of the Faculty of Medicine, Andalas University, Saraswanti Indo Genetech Laboratory Bogor, and Laboratory of $1^{\text {st }}$ base in Singapore.

\section{Identification of Lactic Acid Bacteria (LAB) of Dadih with Polymerase Chain Reaction (PCR)}

Firstly, a bacteria culturing of dadih in de Man Ragosa Sharpe Agar (MRSA) was performed. Secondly, $\pm 2-3$ osecolony of bacterial was put into $1 \mathrm{~mL}$ Phosphate Buffered Saline (PBS). Thirdly, Pellet was isolated based on the kit sample method. DNA isolation step started from digestion, binding, washing, and elution. After the isolation step, the DNA was treated with PCR by using the PCR tool. Before using the PCR tool, provide primer forward (16S63F): 5'-CAG GCC TAA CAC ATG CAA CTC-3' + $273 \mu \mathrm{L}$ buffer TE, primer reverse (16S63F): 5'- GGG CGG AGT GTA CAA GGC-3' + $218 \mu \mathrm{L}$ buffer TE. After that, $10 \mu \mathrm{L}$ of each primer was added with $90 \mu \mathrm{L}$ molecular water. Mixing and running sample compositions can be seen in the following tables 1 and 2 . Furthermore, the sample was sequenced at $1^{\text {st }}$ base Laboratory, Singapore.

Table 1. Sample composition

\begin{tabular}{lc}
\hline \multicolumn{1}{c}{ Composition } & Total $(\mu \mathrm{L})$ \\
\hline dream Taq Green Master & 12.5 \\
Forward primer (16S63F): 5'-CAG GCC TAA CAC ATG CAA CTC-3' & 0.5 \\
Reverse primer (16S63F): 5'- GGG CGG AGT GTA CAA GGC-3' & 0.5 \\
$\mathrm{ddH}_{2} \mathrm{O}$ & 10.0 \\
Pellet sample & 1.5 \\
\hline
\end{tabular}

Table 2. Running condition of sample

\begin{tabular}{lcll}
\hline Running condition & Temperature $\left({ }^{\circ} \mathrm{C}\right)$ & Time & Cycle \\
\hline Pra denaturation & 94 & $3 \mathrm{~min}$ & \\
Denaturation & 94 & $1 \mathrm{~min}$ & 35 \\
Annealing & 30 & $30 \mathrm{sec}$ & $30 \mathrm{sec}$ \\
Extention & 30 & $5 \mathrm{~min}$ & \\
\hline End extension & 72 &
\end{tabular}


Analysis of Amino Acid, according to Nollet (1996) and Water Acquity UPLC H Class (2012)

Amino acid testing was done at Saraswanti Indo Genetech Laboratory- Bogor. Samples of dadih were taken from dadih makers in Agam and Tanah Datar districts. Amino acid hydrolysis with $\mathrm{HCl}$, derivatization of amino acid, and amino acid analysis with UPLC equipment with column condition AccQ. Tag Ultra C18 $1.7 \mu \mathrm{L}(2.1 \mathrm{x}$ $100 \mathrm{~mm}$ ), the temperature at $49^{\circ} \mathrm{C}$, motion phase: gradient system composition, motion flow rate phase: 0.5 $\mathrm{mL} /$ minute, detector: PDA, wave length $260 \mathrm{~nm}$, and volume injection $1 \mu \mathrm{L}$.

\section{$\mathrm{Ca}, \mathrm{Fe}, \mathrm{Zn}$, and I, Mineral Analysis According to AOAC (2011)}

$1 \mathrm{~g}$ of dadih was added into the vessel then added $5 \mathrm{~mL}$ of $\mathrm{HNO}_{3}$. After that, it was extruded with nova wave digestion (ramp: 10" temperature at $150{ }^{\circ} \mathrm{C}$, hold: 15 "). Temperature was gradually lowered to room temperature. Then $25 \mathrm{~mL}$ dadih solution was dissolved with $5 \mathrm{~mL}$ of $\mathrm{HCl}, 1 \mathrm{~mL}$ of $\mathrm{HNO}_{3}$ and aqua bides tuntiltera mark. The last step was the measurement with ICP-OES

\section{Design of Study Follow-up}

This study is an observational design with a prospective cohort study continuation follow up of previous intervention study with experimental quasy design to find out the effect of Dadih and Zinc supplementation during pregnancy on immunity and nutritional status of infants'.

\section{Time and Place}

This study was conducted in Agam District and Bukittinggi City, West Sumatra Province held from April 2018 to December 2018 and held from April to July 2019 for the next follow up.

\section{Population and Sample, Sampling Technique}

The populations of this study were mothers and babies born from the results of the previous study in Bukittinggi City and Agam Regency of West Sumatra Province. The samples consist of 126 infants. Stool and blood were withdrawn. The inclusive criteria are mothers who have been supplemented with Dadih or Dadih Zinc for six months leading to birth. Informed consent was signed by the mothers for willingness to participate in the follow-up study. The exclusion criteria are sickness at the time of initial data collection, or with other congenital defects.

\section{Variables}

The study variables consisted of independent and dependent variables, which included the Dadih supplementation intervention group, the combination of Dadih and Zinc supplementation intervention group and the Control group variables. Dependent variables included immunity status, nutritional status, growth, and development of infants, while the confounding variables are nutrition intake, parenting practices and the characteristics of infants and mothers.

\section{Anthropometry Measurement}

The infants' anthropometry measurements which included weight, height, upper arm circumference (MUAC) were measured using a stadiometer/length-board, calibrated digital weight scale and MUAC tape respectively and caliby trained staff following standard procedures (10). At each test moment, anthropometric measurements were repeated and their average was used calculated z-scores for infants' nutritional status based on WHO standards.

\section{Data Processing and Statistical Analysis}

The data collection was done by cleaning, editing, coding, and analyzing. Those were computerized. Correlation and Chi-square analysis were used to see the trend of child growth and development relationships with each group. Analysis of variance (ANOVA) was used to analyses difference mean dependent variables such as the mean of anthropometric measurements among three groups. The data analysis was performed using SPSS for Windows Version 20.00 for Windows with $\mathrm{p}<0.05$ as a significant level.

\section{Results and Discussion}

Dadih is a food obtained from buffalo milk fermented for $\pm 24-48$ hours. Dadih has a lumpy shape like tofu, a white color, and smells like milk. Sirait (1993) argues that good quality of dadih has white color and milk-like consistency. Sisriyenni and Zurriyati (2004) observed that white color dadih has a soft texture and unique smell which consumers tend to like. Dadih Consistency is affected by chemical components, such as protein, fat, water, and lactic acid bacteria from fermented milk process. The fermentation process uses Lactobacillus bacteria which can be found in milk. This bacteria produces $\beta$-galactosidase that can convert lactose into glucose and galactose. Glucose is converted into fructose 6-fosfat through the glycolysis process. The final result of the glycolysis process is lactic acid. (Horton et al., 2012). 


\subsection{Analysis of Amino Acid}

The purpose of the amino acid analysis is to discover amino acid composition in the sample. The data of amino acid composition in dadih protein aim to increase its nutritional status, by adding deficient essential amino acid (supplementation) or by mixing its protein with other proteins to get better essential amino acid. Dadih has a greater amount of amino acid glutamate than other amino acids (Table 3). Amino acid glutamate exists in D, D, L-, and L- which contribute to form sour taste in food products (Kusnandar 2010). The sour taste in dadih is produced by lactic acid during the fermentation process.

Table 3. Result of amino acid analysis

\begin{tabular}{clcc}
\hline & & \multicolumn{2}{c}{ Composition of Dadih (mg/g) } \\
\cline { 2 - 4 } No & Parameter & Agam & Tanah Datar \\
\hline 1 & Glutamic acid & 16.8 & 15.6 \\
2 & lysine & 7.6 & 6.8 \\
3 & Proline & 6.9 & 6.3 \\
4 & Leucine & 6.6 & 6.2 \\
5 & Aspartic acid & 5.6 & 5.1 \\
6 & Valine & 4.1 & 3.9 \\
7 & Serine & 3.8 & 3.6 \\
8 & Isoleucine & 3.6 & 3.4 \\
9 & Tyrosine & 3.4 & 3.0 \\
10 & Threonine & 3.3 & 3.2 \\
11 & Phenylalanine & 3.0 & 3.0 \\
12 & Alanine & 2.7 & 2.2 \\
13 & Arginine & 2.2 & 2.0 \\
14 & Methionine & 1.8 & 1.6 \\
15 & Histidine & 1.8 & 1.6 \\
16 & Glisine & 1.6 & 1.4 \\
17 & Tryptophan & 1.2 & 0.8 \\
18 & Sistine & 0.3 & 0.3 \\
\hline & & &
\end{tabular}

The result of observation on amino acid analysis (Table 3) shows that glutamate acid is the highest non-essential amino acid in both samples and Lysine while leucine as the highest essential amino acid in the same samples.

Based on the previous research by Helmizar et al. (2019), protein in dadih is estimated to approximately $12.41 \%$ and $49.64 \mathrm{~g}$ of protein per $100 \mathrm{~g}$ of dadih. This means that dadih does not have a sufficient amount of protein to fulfill the nutritional need for pregnant mothers who need a protein intake of $77 \mathrm{~g} /$ day (Indonesian Recommended Daily Intake, 2013). Nevertheless, consuming dadih can fulfill half of the protein need of adults in general.

Table 3 shows that the dadih sample from West Sumatra has a lower nutritional value of amino acid in comparison with previous research (Usmiati, 2012). This research reveals that dadih from West Sumatra has $13.71 \%$ protein. Several elements explain this difference: the location where the dadih was collected, the processing time and the type of buffalo.

Essential amino acid is the amino acid that can not be produced by the human body. Therefore, human beings should consume foods that have essential amino acids. The type of essential amino acid in dadih includes isoleucine, leucine, methionine, phenylalanine, threonine, valine, lysine, histidine (for babies and toddlers), and arginine (for babies only).

Methionine and lysine have limited milk protein synthesis in corn. It shows a low absorption rate in the mammary gland due to the low content of Methionine and Lysin in corn. If the food given has low amino acid, then there will 
be absorption limit and degradation in the rumen. Therefore, it is important to balance the specific amino acid in food to be absorbed in the small intestine (Chow et al., 1990). A non-essential amino acid is an amino acid that can be self-produced by the human body, so it has lower consumption priorities compared to the essential amino acid. The non-essential amino acids in dadih are glycine, alanine, proline, serine, cysteine, tyrosine, aspirin, glutamine, aspartic acid, and glutamate acid.

Table 4. Result of Micro Nutrient Analysis in Dadih

\begin{tabular}{clcc}
\hline \multicolumn{2}{l}{ Composition of Dadih } & & \\
\hline No & \multicolumn{1}{c}{ Micro Nutrient } & Agam & Tanah Datar \\
\hline 1 & Calsium / Ca (mg/100 g) & 190.54 & 247.93 \\
2 & Iodine / I (mcg/100 g) & 15.93 & 16.39 \\
3 & Zinc / Zn (ppm) & 7.03 & 9.27 \\
\hline
\end{tabular}

Analysis of the micronutrient component in dadih samples was done to determine the level of micronutrients as the data can be used as a reference for further study related to the intervention of dadih to pregnant mothers. Referring to Indonesian Recommended Dietary Allowance (2013), pregnant mothers aged 19-49 years need 1100 $\mathrm{mg}$ of calsium, $150 \mathrm{mcg}$ of iodine, and $13 \mathrm{mg}$ of zinc every day. Consuming dadih as much as $100 \mathrm{~g} / \mathrm{day}$ can fulfill calcium needs as much as $219.24 \mathrm{mg} / 100 \mathrm{~g}, 16.16 \mathrm{mcg} / 100 \mathrm{~g}$ of iodine, and $0.01 \mathrm{mg} / \mathrm{g}$ of zinc. Table 4 shows that the need for calcium, iodine and zinc can not be fulfilled by only consuming $100 \mathrm{~g} /$ day by pregnant mothers. Therefore, nutritional needs can be fulfilled by consuming other foods with calcium, iodine, and zinc, such as meat, fish, vegetable, fruits, etc. Other than consuming dadih as much as $100 \mathrm{~g} /$ day, zinc supplement estimated to $20 \mathrm{mg}$ should be given to pregnant mothers.

\subsection{Bacterial Cultures and Molecular identification Probiotic from Dadih}

Every grown bacteria is analyzed with gram coloring to know the positive and negative gram. The result showed that all bacteria is positive gram. Culturing result is identified based on colony morphology, they are the border, surface, size, color, and smell. The colony that has a similar size will be cultured separately. The data showed that 29 colonies were found which consist of 20 aerob and 9 anaerob. The morphology of the colony is diverse, which allows revealing the species. The colony that has different morphology is analyzed further with the sequencing method. Molecular is identified with primer 16sRNA consists of 27F:CGGTTACCTTGTTACGACTT. Both primers will be produced with a size of $1600 \mathrm{bp}$. The size depends on the type of species, which is about $1300-$ $1600 \mathrm{bp}$.

Table 5. Result of BAL identification from dadih with primer 16sRNA

\begin{tabular}{llll}
\hline No & Species & Quantity & $\%$ \\
\hline 1 & Lactobacillus plantarum & 5 & 50 \\
2 & Lactobacillus casei & 2 & 20 \\
3 & Lactobacillus durans & 1 & 10 \\
4 & LeuconostocPseudomesentoroides & 1 & 10 \\
5 & Lactobacillus lactis & 1 & 10 \\
& Total & 10 & 100.0 \\
\hline
\end{tabular}

\subsection{Benefits of Dadih}

Pregnant women belong to groups that are prone to nutritional problems. It can be fatal not only for mothers but also for the mothers the child in her wombs. The nutritional condition of a baby is influenced by current nutritional status in the fetus. In other words, the nutritional status of pregnant women is very important for her health and for predicting pregnancy outcomes for mothers and the nutritional status of newborns (Wibowo et al., 2015). This is due to the fetus's dietary intake that can only go through the umbilical cord connected to the mother's body. The nutritional status of pregnant mothers is reflected in its anthropic size. The size of anthropometry pregnant mothers 
greatly affects the weight of the baby to be born. If the nutritional status of a mother before pregnancy is good, she, will give birth to a healthy baby, enough months and having normal body weight (Helmizar, 2019).

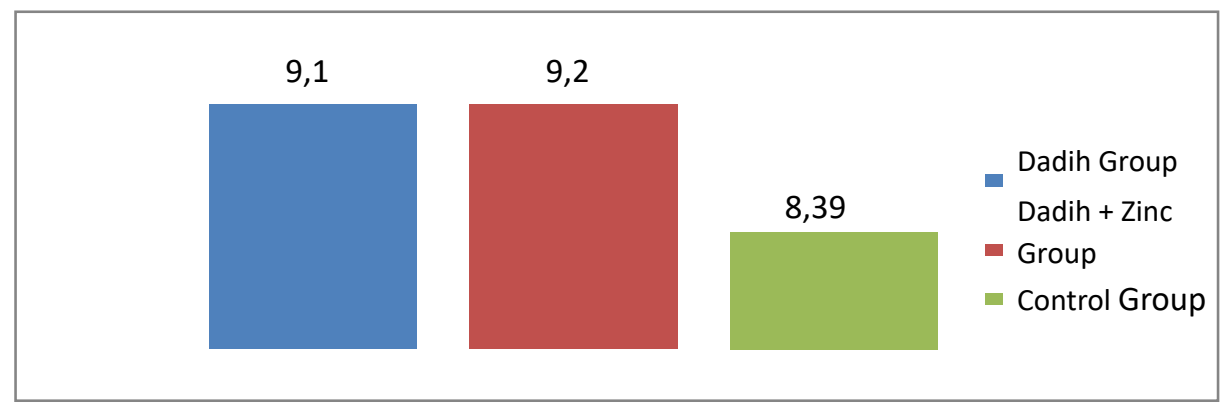

Figure 1. Weight gain of pregnant mothers during six months intervention

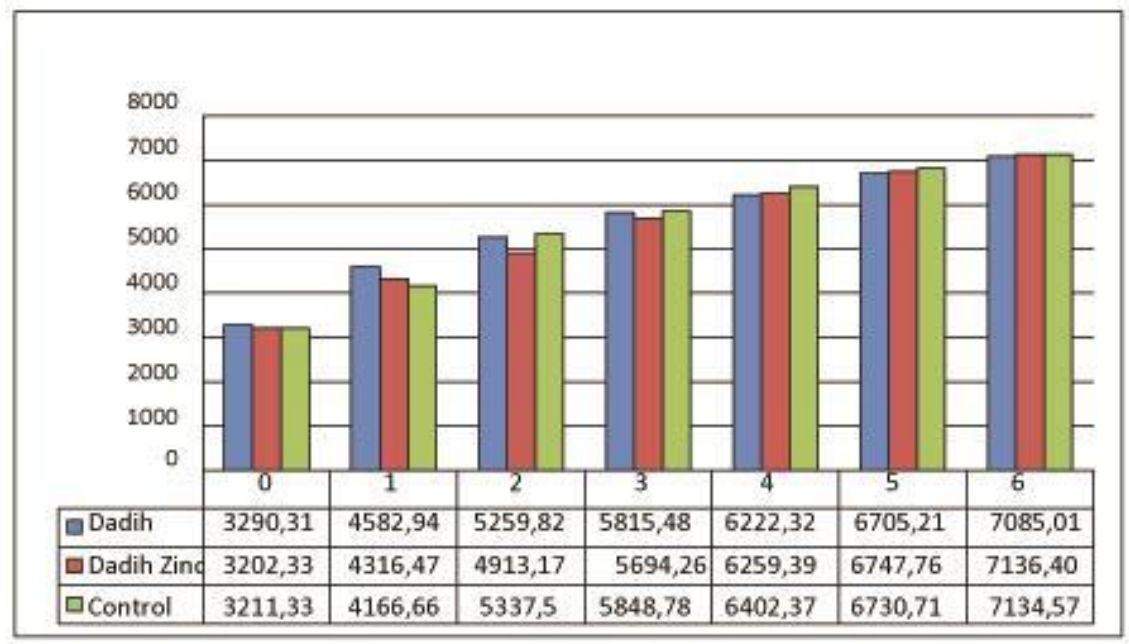

Figure 2. Follow-up infants's birth weight for six months of aged (grams)

Besides intervention to determine weight gain in pregnant women who were divided into 3 groups, namely Dadih, Dadih Zinc, and Control group. The result is the Dadih and Zinc group has the highest weight gain amount 9,26 kilograms and the lowest weight gain is in the Control group with 8,39 kilograms. Based on the diagram above, it can conclude that the highest infant birth weight gain is on Dadih Zinc Group and the lowest is on the Control group. Dadih Zinc group has a constant increase that the other group.

The results of this follow-up study found that there were still infants suffering from stunting, which amounted to $15.9 \%$ found in the three intervention groups. This stunting condition was two times higher in the Control group. In stunting, the child's height does not meet normal height standards according to their ages. Short infants are closely related to conditions that occur in a long time, such as poverty, poor hygiene and healthy behavior, poor environmental health, poor parenting and low levels of education (Rokx, C. 2018). Therefore, further subscriptions are needed to improve the stunting condition suffered by infants at that time. There are solutions for these problems, such as feeding complementary with breast milk and Zinc-fortified local foods to infants that might be carried out in the next phase of research.

\section{Conclusion}

Dadih is a dairy product obtained from fermented buffalo milk in West Sumatra. It contains various species and strains of lactic acid bacteria such as Lactobacillus sp., and Leuconostoc sp., which very beneficial to human health. Lactobacillus sp., L. Plantarum is the dominant species in dadih (50\%). This bacteria produces more than $85 \%$ lactic acid as its metabolite product. L-lactic acid (Dextrorotatory) is a type of lactic acid metabolite that is useful to human health as it can be absorbed quickly and metabolized in the formation of glycogen in the human body. So, therefore, dadih can be used as a source of functional probiotic food to improve health. 
Besides having probiotics, dadih contains various nutrients needed for the human body, including aminoacid. The amount of amino acid is greater in dadih than in dairy milk because lactic acid bacteria in dadih can produce metabolite compounds such as amino acids. Glutamic acid is the highest non-essential amino acid in dadih about $16.28 \mathrm{mg} / \mathrm{g}$, while Lysine and Leucine are about 7.22 and $6.42 \mathrm{mg} / \mathrm{g}$. It is also known that dadih of West Sumatra also contains micronutrients such as calcium $219.24 \mathrm{mg} / 100 \mathrm{~g}$, iodine $16.16 \mathrm{mcg} / 100 \mathrm{~g}$, and zinc $0.01 \mathrm{mg} / \mathrm{g}$. This amount is not enough to fulfill humans' daily nutritional needs. Dadih supplementation and Dadih Zinc supplementation has a positive effect on pregnancy outcomes, lowering the proportion of stunting in infants. Acceleration and growth of infants to achieve optimal growth and development should be carried out before they are under two years old

\section{Acknowledgments}

This study was partly funded by the Directorate General of Research and Development Ministry of Research, Technology and Higher Education of Indonesia. The views expressed herein are those of the individual authors and do not necessarily reflect those of the Indonesian Danone Institute Foundation.

\section{Competing Interest Statement}

The authors declare that there are no competing or potential conflicts of interest.

\section{References}

(AOAC) Association of Analytical Communities. (2011). Official method of calcium, copper, iron, magnesium, manganese, potassium, phosphorus, sodium, and zinc in fortified food product (microwave digestion and ICP OES).

Bouhnik, Y. (1993). Survie et effets chez l'homme des bactéries ingérées dans les laits fermentés. Lait., 73, 241-247. https://doi.org/10.1051/lait:1993222

Charteris, W. P., Kelly, P. M., Morelli, L., \& Collin, J. K. (1998). Ingredient selection criteria for probiotic microorganisms in functional dairy food. Int. J. Dairy Tech., 51(4), 123-135. https://doi.org/10.1111/j.1471-0307.1998.tb02516.x

Helmizar. (2019). Dadih and Zinc Supplementation during Pregnancy Benefits Pregnancy Outcomes and Humoral Immune Response in West Sumatera, Indonesia. In Annals of Nutrition And Metabolism (Vol. 75, pp. 332-332). All schwiler Strasse 10, Ch-4009 Basel, Switzerland: Karger.

Helmizar, Y. E., \& Putra, A. E. (2019). Analysis of Nutrients and Microbiological Characteristics of the Indonesian Dadih as a Food Suplementation. Global Journal of Health Science, 11(1), 155-161. http://doi.10.5539/gjhs.v11n1p.155

Horton, R. H. et al. (2012). Principle of Biochemistry Fifth Edition. United States of America: Pearson.

Pato, U. (2003). Potensi bakteri asam laktat yang diisolasi dari dadih untuk menurunkan risiko penyakit kanker. $J$. Natur Indonesia, 5(2), 162-166.

Rokx, C., Subandoro, A. W., \& Gallagher, P. (2018). Aiming high: Indonesia's ambition to reduce stunting: Main report (English). Washington, D.C.: World Bank Group. Retrieved from http://documents.worldbank.org/curated/en/913341532704260864/main-report

Surono, I. S., Martono, P. D., Kameo, S., Suradji, E. W., \& Koyama, H. (2014). Effect of probiotic L. Plantarum IS-10506 and Zinc supplementation on humoral immune response and Zinc status of Indonesia pre-school infants. Journal of Trace Elements in Medicine and Biology, 28(4), 465-9. https://doi.org/10.1016/j.jtemb.2014.07.009. PMid:25183688.

Suroso, I. S. (2015). Traditional Indonesian dairy foods. Asia Pac J Clin Nutr., 24(suppl 1), S26-S30. https://doi.org/10.6133/apjen

Suroso, I. S., Martono, P. D., Kameo, S., Suradji, E. W., \& Koyama, H. (2014). Effect of probiotic L. Plantarum IS-10506 and zinc supplementation on humoral immune response and zinc status of Indonesia pre-school children. J Trace Elem Med Biol., 28, 465-9. https://doi.org/10.1016/j.jtemb.2014.07.009. PMid:25183688.

Syah, N. P. (2006). Health Benefits of Yogurt and Fermented Milk; Manufacturing Yogurt and Fermented Milk. NewYork, USA: Blackwell Publishing.

Tannock, G. W. (1999). Probiotic: A Critical Review. England: Horizon Scientific Press.

Usmiati, \& Risfaheri. (2012). Improvement od Dadih as an indigenous Probiotic Function Food of West Sumatra. J. Litbang Pert., 2(1), 20-29. 
Venema, H., \& Surono, I. S. (2018). Microbiota composition of dadih- a traditional fermented buffalo milk of West Sumatra. Letters in Applied Microbiology, 68, 234-240. https://doi.org/10.1111/lam.13107. PMid: 30565283 PMCid:PMC6849839.

Waters, C. (2012). Acquity UPLC H-Class and H-Class Bio amino Acid Analysis System Guide; Revision B. Water Corporation, USA.

Wibowo, N., Mose, J. C., Karkata, M. K., Purwaka, B. T., Kristatnto, H., Chalid, M. T. et al. (2015). The Status of Probiotic Supplementation during Pregnancy. Medical Journal Indonesia. https://doi.org/10.13181/mji.v24i2.1223

\section{Copyrights}

Copyright for this article is retained by the author(s), with first publication rights granted to the journal.

This is an open-access article distributed under the terms and conditions of the Creative Commons Attribution license (http://creativecommons.org/licenses/by/4.0/). 